\title{
Self-Renewal, Pluripotency and Tumorigenesis in Pluripotent Stem Cells Revisited
}

\author{
Yanzhen Li and Tetsuya S. Tanaka \\ Department of Animal Sciences, Institute for Genomic Biology, \\ University of Illinois at Urbana-Champaign
}

USA

\section{Introduction}

Embryonic stem cells (ESCs) are derived from preimplantation embryos and are capable of both long-term proliferation (self-renewal) and differentiation into cell types of all three germ layers (pluripotency). The self-renewal and pluripotency of ESCs are sustained by certain essential transcription factors. Intriguingly, the viral transduction of these transcription factors into differentiated adult somatic cells results in reprogramming of the developmental process that the somatic cells have undergone. Consequently, pluripotent cells similar to ESCs, termed induced pluripotent stem cells, can be artificially established from specialized cells. These two types of pluripotent stem cells (PSCs) have held the promise of providing customized tissue replacements as well as platforms for drug screening since they were derived from human tissues and embryos. However, the heterogeneous nature of PSC cultures, which may reflect the plasticity of early embryonic cells, hampers the establishment of a definitive and reproducible culture microenvironment. In addition, the induction of PSC differentiation is dependent on random events and generates heterogeneous populations of specialized cells. Furthermore, PSCs, by definition, are able to generate benign tumors called teratomas, which consist of cell types of three germ layers. To prevent the growth of teratomas in therapeutic transplanted tissue replacements, it is necessary to establish techniques for efficiently manipulating cell fate decisions in PSCs and to understand the mechanism responsible for tumorigenesis in the stem cells. To our surprise, the mechanism of teratoma formation from PSCs has received little attention to date. Thus, in order to better understand self-renewal, pluripotency and tumorigenesis in PSCs, this chapter will address the following three simple but overlooked questions:

1. Does every pluripotent stem cell possess identical self-renewal capability?

2. Are current standard culture conditions optimal for maintaining pluripotent stem cells?

3. Is tumorigenesis an inherent feature of cellular pluripotency?

Accumulating experimental evidence, including our recent studies using mouse ESCs as a model, indicates that the self-renewal of PSCs can be easily compromised by extrinsic factors in the culture microenvironment that can turn the stem cells tumorigenic. Thus, the safety of PSC-based therapy may be significantly improved by more careful manipulation and definition of the cellular microenvironment. 


\section{Pluripotent stem cells generate heterogeneous populations}

\subsection{Pluripotent stem cells}

Pluripotent stem cells (PSCs) are an excellent model to study mechanisms of cellular pluripotency and differentiation in vitro because of their capacity for self-renewal and their capability to become most kinds of specialized cells, including germ cells. The identification and characterization of a mouse strain that naturally develops testicular teratoma (Stevens \& Little, 1954; Stevens, 1973) contributed to demonstrating that teratomas originate from PSCs (Solter, 2006). A benign teratoma, normally found in 1 out of 40,000 live births (Barksdale \& Obokhare, 2009), is a "monstrous" tumor consisting of specialized cells derived from all three germ layers (ectoderm, mesoderm and endoderm). The first PSCs, embryonic carcinoma cells (ECCs), were derived from malignant teratocarcinomas, which were experimentally generated by transplantation of peri-implantation embryos into the testes of host animals (Stevens, 1970). ECCs are transplantable, in that they will develop into teratocarcinomas when transplanted. Because ECCs are pluripotent, the original study established an in vitro system to study the cell fate decision mechanism. Furthermore, this study indicated that there could be another kind of PSCs in early embryos that could be directly established by in vitro culture, but not by transplantation, of early embryos. During mouse preimplantation development, the first cell differentiation event gives rise to the pluripotent inner cell mass (ICM) and the lineage-committed trophectoderm. When cultured on embryonic fibroblasts, the ICM gives rise to pluripotent stem cells. Mouse embryonic stem cells (ESCs) were successfully derived in 1981 (Martin, 1981; Evans \& Kaufman, 1981) and have been the primary model used to investigate mechanisms of cell fate decision. Similar PSCs were later established from primordial germ cells, namely embryonic germ cells (Matsui et al., 1992). These studies on mouse embryos paved the way for the derivation of embryonic stem and germ cells from human embryos (Thomson et al., 1998; Shamblott et al., 1998). The derivation of PSCs from human embryos shed light on regenerative medicine and helped to expand this field of research (Tanaka, 2010). ESCs have been derived from a variety of species (Tanaka, 2010). Studies on self-renewal and pluripotency using ESCs further enabled the establishment of other kinds of PSCs, including early primitive ectoderm-like stem cells (EPLCs; Rathjen et al., 1999) and epiblast-derived stem cells (EpiSCs; Brons et al., 2007; Tesar et al., 2007). Because EpiSCs are derived from, and EPLCs are thought to be equivalent to, cells of post-implantation embryos, their capabilities to generate differentiated cells are more restricted than those of ESCs (Hiratani et al., 2010). That is, embryonic development proceeds by restricting a cell's ability to generate specialized cells. Therefore, a method to erase such acquired restrictions in specialized cells was sought in order to restore differentiated cells to the pluripotent state. This was first achieved by transferring somatic cell nuclei into enucleated oocytes (Briggs \& King, 1952; Campbell et al., 1996; Wakayama et al., 1998; Rideout et al., 2002; Gurdon \& Melton, 2008). Intriguingly, recent studies have shown that delivering extra copies of four transcription factors that orchestrate self-renewal and pluripotency into differentiated cells results in the reprogramming of the specialized cells into PSCs, called induced pluripotent stem cells (iPSCs; Takahashi \& Yamanaka, 2006). Since the successful derivation of iPSCs from human cells (Takahashi et al., 2007; Yu et al., 2007), iPSCs have been considered to hold great potential for developing customized replacement tissues and for providing platforms for drug screening. However, cells differentiated from PSCs in vitro that have been transplanted into animal disease models (for example, Kerr et al., 2003; Brederlau et al., 2006; Jomura et al., 
2007) tend to develop into teratomas due to residual populations of undifferentiated PSCs. Thus, a better understanding of extrinsic and intrinsic factors involved in cell fate decisions and tumorigenesis in PSCs is necessary to significantly improve iPSC-based stem cell therapy.

\subsection{Extrinsic factors for maintenance of self-renewal}

The derivation of ESC lines from human and mouse embryos could not have been accomplished without feeder layers of embryonic fibroblasts. Although cultured ECCs do not require a layer of feeder cells for growth, both embryonic germ cell and iPSC cultures do. Interestingly, conditioned medium (CM) from embryonic fibroblasts was sufficient to support the culture of undifferentiated mouse ESCs in the absence of feeder layers (Smith \& Hooper, 1983). Analysis of components in CM led to the identification of the leukemia inhibitory factor (LIF) as a differentiation inhibitor (Smith et al., 1988; Williams et al., 1988). These studies laid the foundation for investigating the dependence of self-renewal and pluripotency of ESCs on other extrinsic factors. In addition to LIF, the maintenance of mouse ESC culture requires Bone morphogenetic protein 4 (Bmp4; Ying et al., 2003), vitamin A (retinol and retinoic acid; Chen \& Khillan, 2008; Wang et al., 2008; Chen \& Khillan, 2010), threonine (Wang et al., 2009) and a decreased oxidation state (Yanes et al., 2010). The existence of another extrinsic factor independent from the LIF/Stat3 signal, namely ES cell renewal factor, has also been postulated (Dani et al., 1998). The supplementation of basal culture media with animal sera, such as fetal bovine serum (FBS), provides all of these extrinsic factors except LIF. Although human ESCs are similar to mouse ESCs with respect to their self-renewal and pluripotency, the extrinsic factors necessary for mouse ESC culture failed to support the culture of human ESCs. For example, the combination of LIF and serum could not support long-term self-renewal of human ESC lines (Bongso et al., 1994). Furthermore, Bmp4 promoted differentiation of human ESCs into trophoblasts (Xu et al., 2002), whereas long-term proliferation of these cells was maintained in the presence of Noggin, an antagonist of Bmp4 (Wang et al., 2005; Xu et al., 2005b). Instead, the maintenance of human ESC self-renewal and pluripotency mainly relies on basic fibroblast growth factor (bFGF; $\mathrm{Xu}$ et al., 2005a). In addition, members of the transforming growth factor $\beta$ (TGF $\beta$ ) superfamily, especially TGF $\beta$, activin and Nodal, are essential for maintaining the pluripotency of human ESCs in combination with bFGF (Beattie et al., 2005; James et al., 2005; Vallier et al., 2005). Mouse and human iPSCs exhibit dependency on extrinsic factors similar to mouse and human ESCs, respectively. Mouse and rat EpiSCs are dependent on activin and bFGF to sustain self-renewal and pluripotency, and thus human ESCs are more similar to these EpiSCs. These discrepancies are attributed to differences in development between mouse and human embryos, even though mouse and human ESCs have been derived from embryos at similar developmental stages. Very interestingly, it has been suggested that the reprogramming process makes human iPSCs more similar to mouse ESCs (Hanna et al., 2010). ECCs do not exhibit dependency on extrinsic factors, whereas the maintenance of embryonic germ cells requires LIF, bFGF and the c-Kit ligand, Steel factor (Matsui et al., 1991; Matsui et al., 1992). Thus, signals from these extrinsic factors may converge in maintaining the activity of a common set of intrinsic genetic factors that define cellular "stemness".

\subsection{Intrinsic factors to maintain self-renewal}

Maintenance of the self-renewal and pluripotency of mouse ESCs relies on the activity of the downstream target of the LIF signal, the Stat3 transcription factor (Niwa et al., 1998; 
Matsuda et al., 1999). However, key players further downstream of Stat3 are essential for these processes because the LIF/Stat3 signaling pathway is not required for the maintenance of pluripotent cells in developing embryos or for the self-renewal and pluripotency of human ESCs (Dani et al., 1998; Tanaka, 2009). This pathway may interact with the transcription factors Oct3/4/ Pou5f1 (Nichols et al., 1998; Niwa et al., 2000), Sox2 (Avilion et al., 2003; Masui et al., 2007), Nanog (Chambers et al., 2003; Mitsui et al., 2003), Klf4 (Li et al., 2005) and c-Myc (Cartwright et al., 2005). In a steady state, a balance of the relative expression levels of these genes is essential for fate decisions of mouse ESCs (Fujikura et al., 2002; Niwa et al., 2005). The genetic network of these transcription factors and the expression of their downstream target genes have been elucidated by genomic approaches (Ivanova et al., 2002; Ramalho-Santos et al., 2002; Tanaka et al., 2002; Boyer et al., 2005; Loh et al., 2006; Matoba et al., 2006; Walker et al., 2007). These genomic approaches revealed that cellular pluripotency is characterized by the expression of a unique set of genes that suppress transcripts associated with cellular differentiation. Recently, the self-renewal of mouse ESCs was shown to be maintained by simple pharmacological inhibition of Erk, which is downstream of FGF receptors, and the inhibition of Gsk3 $\beta$ activity (Ying et al., 2008). Because mouse ESCs express Fgf4 (Wilder et al., 1997), these studies indicate that ESCs maintain self-renewal by competing against their own differentiation-inducing signals. Mouse and human ESCs express Wnt (Nordin et al., 2008; Lako et al., 2001; Okoye et al., 2008), which is the biological inhibitor of Gsk3 $\beta$, and the pharmacological inhibition of Gsk3 $\beta$ alone promotes self-renewal of both mouse and human ESCs (Sato et al., 2004) as well as derivation of ESCs from the ICM (Umehara et al., 2007). However, exogenous Wnt promotes the differentiation of mouse (Lindsley et al., 2006) and human (Wang \& Nakayama, 2009) ESCs. Thus, the role of Wnt in the self-renewal of ESCs requires further investigation. Finally, a comparison of global gene expression profiles of mouse ESCs of different genetic backgrounds, teratocarcinoma cells (ECCs) and embryonic germ cells showed that the expression of Rex1 was higher in cells with greater pluripotency (Sharova et al., 2007). The zinc-finger protein Rex $1 / Z f p 42$ was originally identified as one of the genes whose expression was downregulated when the teratocarcinoma cell line F9 was induced to differentiate by retinoic acid (Hosler et al., 1989). However, the targeted knockout of Rex1 revealed that it is not required for the maintenance of self-renewal (Masui et al., 2008). There are several genes expressed specifically in pluripotent embryonic cells at significant levels, which do not play any essential role in pluripotency (e.g., Esg1/Dppa5; Western et al., 2005; Amano et al., 2006; Tanaka et al., 2006).

\subsection{Transcriptional heterogeneity in pluripotent stem cells}

One of the challenges in understanding the mechanism of self-renewal and pluripotency of PSCs is that cultured ESCs consist of cell populations that show fluctuating expression of genes. That is, a bulk preparation of ESCs may only show an averaged state of ESCs and thus obscure the presence of distinct ESC populations. Therefore, a better understanding of gene expression at the cellular level is critical. In fact, several groups have performed expression microarray analyses at the single-cell level and have revealed populations of cells that differ in their transcript profiles (Crino et al., 1998; Chiang \& Melton, 2003; Kurimoto et al., 2006; Ramos et al., 2006; Tang et al., 2010). Several studies, including ours, have found that well-maintained mouse ESC cultures consist of a small percentage of cells that show fluctuating expression levels of genes such as Dppa3 (Stella/Pgc7; Payer et al., 2006; Hayashi 
et al., 2008), Nanog (Chambers et al., 2007; Singh et al., 2007), Pecam1 (Furusawa et al., 2004; Furusawa et al., 2006), Rex1 (Toyooka et al., 2008) and Zscan4 (Falco et al., 2007; Zalzman et al., 2010), or genes associated with cell differentiation, such as Brachyury/T (Suzuki et al., 2006a; Suzuki et al., 2006b), Rhox6/9 (Carter et al., 2008), Tcf15 and Twist2 (Tanaka et al., 2008). These genes are either downregulated (Nanog and Rex1) or expressed (the rest) in about one-tenth of cells in culture as a steady state (Fig. 1; Tanaka, 2009). Mouse ESCs showing fluctuating expression of Nanog, Rex1, T, Dppa3 and Zscan4 have been extensively characterized. When mouse ESCs were sorted according to expression levels of one of these genes and cultured separately, the resulting ESC populations eventually showed similar fluctuating expression of the gene. For example, when sorted Zscan4-positive and -negative subpopulations were replated and cultured separately, both subpopulations regained Zscan4-negative and -positive cells, respectively (Zalzman et al., 2010). Each subpopulation possessed a unique differentiation potential. Thus, the heterogeneous nature of PSCs may reflect the plasticity of early embryonic cells (Hayashi et al., 2008; Zalzman et al., 2010). The underlying mechanism

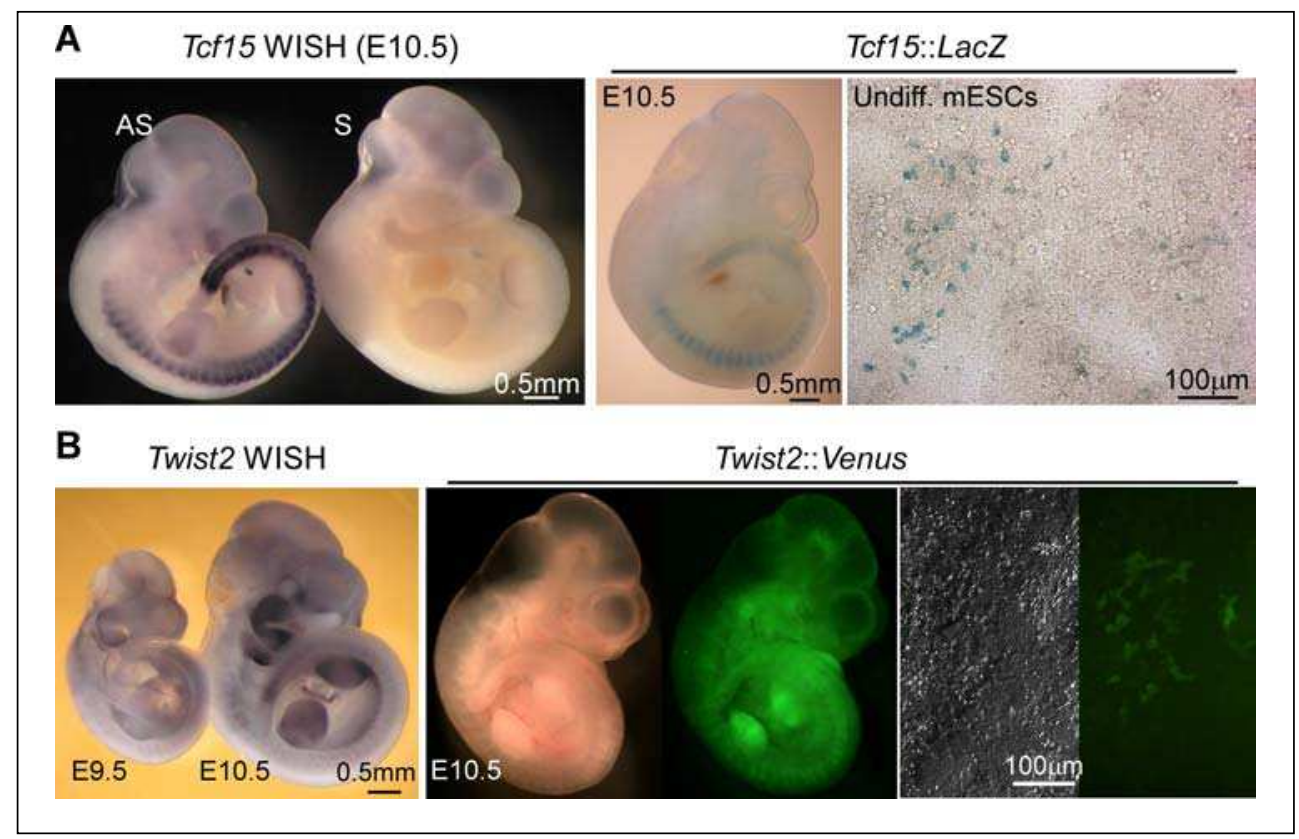

Fig. 1. Standard culture of mouse embryonic stem cells (ESCs) exhibit fluctuating expression of genes (modified from Tanaka et al., 2008). (A, left) The Tcf15 expression pattern in a 10.5 days post-conception (d.p.c.) embryo shown by whole-mount in situ hybridization (WISH). S, sense (negative) control. (A, right) Expression of a reporter (LacZ) under the Tcf15 promoter in a 10.5 d.p.c. embryo derived solely from the mouse ESCs by tetraploid aggregation and in undifferentiated mouse ESCs plated on gelatin-coated dishes (Undiff. mESCs). (B, left) Twist2 expression patterns in 9.5 and 10.5 d.p.c. embryos examined as in A. (B, right) Expression of a fluorescent reporter (Venus) under the Twist2 promoter in a 10.5 d.p.c. embryo derived solely from mouse ESCs and in undifferentiated mouse ESCs. 
responsible for inducing the transcriptional heterogeneity in ESCs remains largely unknown. However, as will be discussed in the following sections, ESCs in culture may have received some signals from the microenvironment, such as the stiffness of culture dishes and serum components, which initiate the heterogeneous transcription of these genes.

\section{Impacts of culture conditions on the self-renewal of pluripotent stem cells}

\subsection{Stiffness of a culture dish}

When LIF is supplied in the culture medium, mouse ESCs can be maintained on gelatincoated plates without a layer of embryonic fibroblasts as feeders (Robertson, 1987). Similarly, human ESCs can be maintained on plates coated with Matrigel (a basement membrane preparation extracted from a murine Englebreth-Holm-Swarm sarcoma) independent of a feeder layer in a chemically defined culture medium. Interestingly, other extracellular matrix proteins elicit different responses from ESCs. For example, collagen IA promotes the self-renewal of mouse ESCs (Furue et al., 2005), and fibronectin and laminin



Fig. 2. Soft substrates promote mouse embryonic stem cell self-renewal. Mouse ESCs were plated on substrates that have the same stiffness as mouse ESCs (A-C) or on glass-bottomed dishes (D-F) and maintained under standard culture conditions with LIF (A \& D) or without LIF for 5 days $(\mathbf{B}, \mathbf{C}, \mathbf{E} \& \mathbf{F})$. Bars, $50 \mu \mathrm{m}$. (A \& D) In the presence of LIF, mouse ESCs typically formed round colonies (top) on collagen type IA-coated surfaces and maintained Oct3/4 expression, indicated by the enhanced green fluorescent protein (EGFP) driven by the Oct3/4 promoter (Oct3/4::EGFP, bottom). (B \& C) Mouse ESCs on soft substrates without LIF for 5 days formed round colonies that maintained active alkaline phosphatase $(\mathbf{B})$ and the expression of Nanog (C). (E \& F) Mouse ESCs on a glass-bottomed dish without LIF for 5 days exhibited appearance of differentiated cells with no detectable alkaline phosphatase activity (E) or Nanog expression (F). 
help decrease their differentiation potential (Hayashi et al., 2007; Hayashi et al., 2010). Collagen IV is an inducer of mesoderm lineages for both mouse and human ESCs (SchenkeLayland et al., 2007). Intriguingly, the analysis of Matrigel components has led to the discovery of synthetic polymers that can support the long-term self-renewal of human ESCs (Melkoumian et al., 2010; Rodin et al., 2010; Villa-Diaz et al., 2010). Recently, it has become evident that cell fate decisions in stem cells are regulated by matrix elasticity or substrate stiffness (Discher et al., 2009). For example, synthetic soft substrates (Elasticity, $\mathrm{E}=\sim 1 \mathrm{kPa}$ ) that mimic the elasticity of the brain induced the differentiation of neurons from mesenchymal stem cells, whereas stiffer substrates $(\mathrm{E}=\sim 40 \mathrm{kPa})$ that mimic the elasticity of collagenous bone induced the differentiation of osteoblasts (Engler et al., 2006). In contrast, we found that mouse ESCs are intrinsically soft and respond optimally to physical forces when cultured on substrates that match their intrinsic softness, which is $0.6 \mathrm{kPa}$ (about 7000 fold softer than plastic culture dishes; Chowdhury et al., 2010). In culture conditions, mouse ESCs are grown on much harder substrates than any tissue in vivo. To investigate the effect of soft substrates on the self-renewal of mouse ESCs, we plated a mouse ESC line expressing enhanced green fluorescent protein (EGFP) under the Oct3/4 promoter (Fig. 2A \& D; Walker et al., 2007) on either soft substrates or glass-bottomed dishes in the absence of LIF for 5 days. Remarkably, mouse ESCs on the soft substrate grew as uniformly round colonies without any noticeable differentiating colonies (see Fig. 2E) and were able to maintain the expression of markers for pluripotent cells: Oct3/4 (data not shown), alkaline phosphatase (Fig. 2B) and Nanog (Fig. 2C). Mouse ESCs cultured on a glass-bottomed dish fully differentiated and downregulated these markers (Fig. 2E \& F). Therefore, these results strongly indicate that substrate stiffness is a critical extrinsic factor to sustain the selfrenewal of mouse ESCs (Chowdhury et al., 2010).

\subsection{Culture conditions with animal serum}

Animal serum provides nutrients, hormones, growth factors, steroids and matrix proteins to cultured cells. It also contains remnants of plasma components used for the activation and processing of blood clots as well as other substances that do not normally pass through the endothelial barrier (Hewlett, 1991; Holliday, 1999; Sato et al., 2010). Despite the fact that animal serum is similar but not identical to the interstitial fluid (i.e., lymph) that surrounds cells in vivo, animal serum is preferred for cell culture because it significantly improves the growth of cells. However, animal serum is also known to negatively impact cells in culture (Sato, 1975). For example, complement in serum may inhibit cell growth; these components may be inactivated by heat (Robertson, 1987). In addition, serum promotes aneuploidy in cultured cells (Loo et al., 1987) that may contribute to the incidence of chromosomal instability in mouse ESCs (Rebuzzini et al., 2008). In fact, no cell types in vivo are exposed to serum for extended periods, except the ones in the vicinity of a wound where clotting has taken place (Barnes \& Sato, 1980). Because animal serum provides cell culture with many other uncharacterized components that may compromise the capability of PSCs to selfrenew and differentiate, only qualified animal serum can be used for PSC culture (Robertson, 1987). Furthermore, animal products cannot be used to maintain human iPSCs for transplantation purposes (Ludwig et al., 2006b). Although attempts have been made to culture human ESCs in human serum, these cells exhibited extensive differentiation (Rajala et al., 2007). Chemically defined culture is a preferable alternative, as it not only allows us to obtain more consistent results for better manipulation of PSC differentiation, but can also be applied to practical therapeutic uses for iPSCs. 


\subsection{Serum-free culture conditions}

To eliminate the effects of unknown components in animal serum, chemically defined serum-free culture methods have been established for PSCs (Ying et al., 2003; Furue et al., 2005; Ludwig et al., 2006a; Ludwig et al., 2006b; Furue et al., 2008). Typically, these defined culture media are composed of critical growth factors (e.g., LIF and Bmp4) and other factors present in animal sera, such as hormones (e.g., insulin and transferrin), vitamins, fatty acids and minerals. In addition, a pre-mixed serum replacement that claims to include no animal serum components was introduced in 1998 (Goldsborough et al., 1998; Cheng et al., 2004). Although the exact components in the serum replacement cannot be disclosed by its patent (Price et al., 1998), the patent indicates that it contains at least albumin, amino acids, vitamins, transferrin, antioxidants, insulin, collagen precursors and some trace elements. In spite of the fact that the serum replacement successfully supported the growth of primate ESCs (e.g., Suemori et al., 2001), human ESCs cultured with this preparation indicated the presence of some BMP-like factors that induced the differentiation of trophoblasts $(\mathrm{Xu}$ et al., 2005b). The maintenance of the undifferentiated state of both mouse and human ESCs using defined culture media has been well documented (Ludwig et al., 2006a; Ludwig et al., 2006b; Hayashi et al., 2007; Ying et al., 2008), and the pluripotency of these mouse ESCs has been validated by their differentiation in vitro (Furue et al., 2005; Hayashi et al., 2007) and by the development of chimeric mice (Ying et al., 2003).

\section{Tumorigenesis in pluripotent stem cells}

\subsection{Intrinsic factors involved in tumorigenesis}

The ability of cells to grow as a teratoma after transplantation into a host animal is a hallmark of cellular pluripotency (see "2.1 Pluripotent stem cells"; Chambers \& Smith, 2004; Solter, 2006; Jaenisch \& Young, 2008; Damjanov \& Andrews, 2007; Lensch \& Ince, 2007). Testing this cellular ability requires no special techniques or equipment and reduces the use of experimental animals, and it is particularly useful and widely accepted for the validation of pluripotency in human PSCs (Yu \& Thomson, 2008). However, this cellular ability is the major critical safety issue hampering the therapeutic application of human iPSCs (Yamanaka, 2009). According to Lawrenz et al. (2004), two mouse ESCs were sufficient able to grow into a teratoma only when mixed with $2 \times 10^{6}$ non-tumorigenic fibroblasts (MRC-5) prior to transplantation into immunocompromised mice. To date, little is known about the tumorigenic property of PSCs, except that the oncogene Eras is responsible for the tumor-like growth of mouse ESCs (Takahashi et al., 2003). It is interesting to note that Eras activates Akt (Takahashi et al., 2003) and that constitutive activation of Akt is sufficient to drive self-renewal of mouse and non-human primate ESCs (Watanabe et al., 2006). In addition, Akt mediates the inactivation of Gsk3 $\beta$ by insulin via phosphorylation (Bechard \& Dalton, 2009; Wu \& Pan, 2010; Cross et al., 1995). Gsk3 $\beta$ inhibits its downstream target c-Myc through $\beta$-catenin (He et al., 1998; Bechard \& Dalton, 2009), so Eras may indirectly activate c-Myc, which is responsible for the selfrenewal of mouse ESCs (Cartwright et al., 2005) and for tumorigenesis in mouse iPSCs (Okita et al., 2007; Nakagawa et al., 2010). However, this model may involve other uncharacterized gene products, as human ESCs do not express human ERAS (Kameda \& Thomson, 2005; Tanaka et al., 2009) but develop into teratomas. 


\subsection{Extrinsic factors responsible for tumorigenesis}

Interestingly, mouse PSCs contribute to the development of normal chimeras, instead of forming teratomas, when mixed with mouse preimplantation embryos (Bradley et al., 1984; Auerbach et al., 2000; Polo et al., 2010). Thus, mouse PSCs may require proper extrinsic signals or niches (Voog \& Jones, 2010) to differentiate normally and to contribute to the development of chimeras. The fact that mouse PSCs behave differently when exposed to different microenvironments raises the question of whether PSCs are inherently tumorigenic or are provided with extrinsic signals in vitro that promote tumor-like growth. To address this question, we transferred mouse ESCs maintained under standard conditions (Fig. 3A) using fetal bovine serum (FBS) into chemically defined serum-free (CDSF) conditions (Fig. 3B).

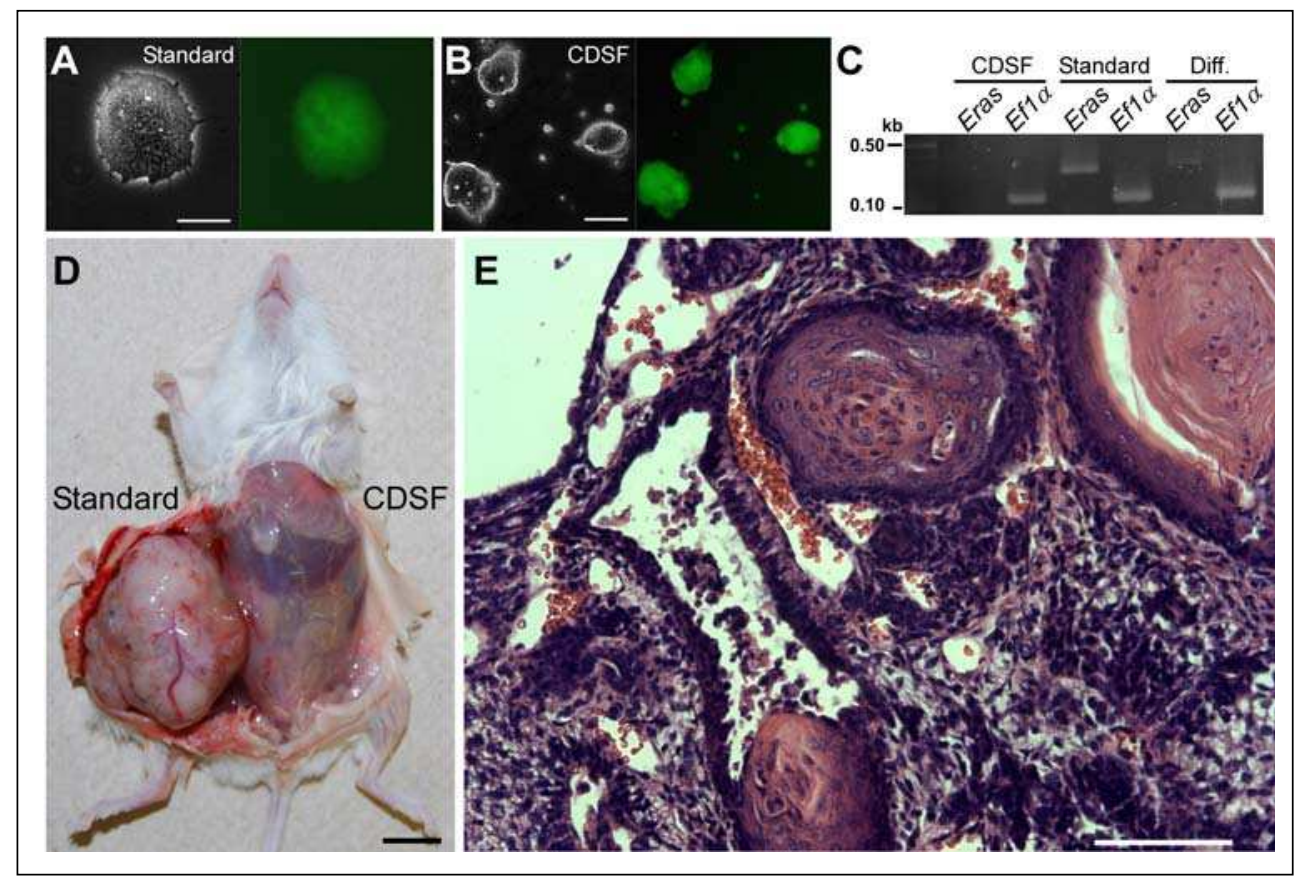

Fig. 3. Mouse embryonic stem cells gain tumorigenicity from animal serum. (A) A mouse ESC line that harbors an EGFP reporter driven by the Oct3/4 promoter (right) was maintained under standard conditions using fetal bovine serum (FBS). Bar, $50 \mu \mathrm{m}$. (B) The same ESC line shown in (A) was plated on a collagen IA-coated plate and cultured under chemically defined serum-free (CDSF) conditions. The transcriptional activity of Oct $3 / 4$ is evidenced by the green fluorescence (right). Bar, $50 \mu \mathrm{m}$. (C) Expression of Eras was examined in mouse ESCs cultured under the indicated conditions. Diff., ESC differentiation was induced by the withdrawal of LIF for 5 days. Ef1a is shown as a control. (D) $1 \times 10^{6}$ cells maintained under each indicated condition were transplanted subcutaneously into NODSCID mice, and their growth was monitored for 11 weeks. Bar, $1 \mathrm{~cm}$. (E) Histological image of a teratoma consisting of a variety of specialized cells. Bar, $100 \mu \mathrm{m}$. 
These ESCs were maintained under CDSF conditions for three passages before being subcutaneously transplanted into immunocompromised mice. Surprisingly, the ESCs failed to produce teratomas for up to six months, whereas mouse ESCs maintained under standard conditions generated well-developed teratomas within five weeks (Fig. 3D \& E). When mouse ESCs were cultured under CDSF conditions supplemented with FBS, or when the cells were cultured under CDSF conditions followed by standard culture conditions, they consistently developed into teratomas. The tumorigenic plasticity of mouse ESCs appears to be unique; ECCs (F9; Bernstine et al., 1973) cultured in CDSF formed teratomas when transplanted (data not shown). Because serum is different from interstitial fluid (i.e., lymph), it is suggested with our present data that interstitial fluid will not provide tumorigenicity. Mouse ESCs cultured under CDSF conditions proliferated significantly more slowly than mouse ESCs cultured under standard conditions. Their slower proliferation was accompanied by the downregulation of Eras (Fig. 3C), which is responsible for the tumorigenicity of mouse ESCs. However, mouse ESCs cultured under CDSF conditions maintained the expression of transcripts associated with cellular pluripotency, Oct3/4 (Fig. 3B), Sox2 and Esg1 (data not shown; see "2.3 Intrinsic factors to maintain self-renewal"). These results indicate that the tumorigenicity of mouse ESCs is reduced without compromising the pluripotency by short-term serum-free culture (Li \& Tanaka, submitted). Perhaps these mouse ESCs exhibited cell death after transplantation due to the absence of a continuous supply of LIF (Furue et al., 2005), even though mouse ESCs express their own LIF transcripts (Shen \& Leder, 1992). Because the effect of long-term serum-free culture on tumorigenesis in mouse ESCs has not yet been evaluated, we cannot rule out the possibility that undifferentiated mouse ESCs that have adapted to long-term serum-free culture may regain tumorigenic properties.

\section{Conclusion}

Here we present experimental evidence to suggest that soft substrates promote mouse ESC self-renewal and that short-term serum-free culture reduces the tumorigenicity of mouse ESCs. The underlying mechanisms involved in the cell-substrate interaction and tumorigenesis in mouse ESCs are currently unknown. However, these studies using mouse ESCs provide a basis for further study and help establish simple strategies to significantly enhance the control of differentiation and increase the safety of human iPSCs.

\section{Acknowledgement}

The authors are deeply grateful to Dr. Ning Wang and Mr. Farhan Chowdhury for sharing results with us and Dr. Miho Kusuda Furue for discussing the data. The work presented here was supported by the USDA Hatch Project (ILLU-538-323), University of Illinois and the Illinois Regenerative Medicine Institute.

\section{References}

Amano, H., K. Itakura, M. Maruyama, T. Ichisaka, M. Nakagawa and S. Yamanaka (2006). Identification and targeted disruption of the mouse gene encoding ESG1 (PH34/ECAT2/DPPA5). BMC Dev Biol, 6, 1, (Feb 2006) 11, 1471-213X 
Auerbach, W., J. H. Dunmore, V. Fairchild-Huntress, Q. Fang, A. B. Auerbach, D. Huszar and A. L. Joyner (2000). Establishment and chimera analysis of 129/SvEv- and C57BL/6-derived mouse embryonic stem cell lines. Biotechniques, 29, 5, (Nov 2000) 1024-32, 0736-6205

Avilion, A. A., S. K. Nicolis, L. H. Pevny, L. Perez, N. Vivian and R. Lovell-Badge (2003). Multipotent cell lineages in early mouse development depend on SOX2 function. Genes Dev., 17, 1, (Jan 2003) 126-140, 0890-9369

Barksdale, E. M., Jr. and I. Obokhare (2009). Teratomas in infants and children. Curr Opin Pediatr, 21, 3, (Jun 2009) 344-9, 1531-698X

Barnes, D. and G. Sato (1980). Serum-free cell culture: a unifying approach. Cell, 22, 3, (Dec 1980) 649-55, 0092-8674

Beattie, G. M., A. D. Lopez, N. Bucay, A. Hinton, M. T. Firpo, C. C. King and A. Hayek (2005). Activin A maintains pluripotency of human embryonic stem cells in the absence of feeder layers. Stem Cells, 23, 4, (Apr 2005) 489-95, 1066-5099

Bechard, M. and S. Dalton (2009). Subcellular localization of glycogen synthase kinase 3beta controls embryonic stem cell self-renewal. Mol Cell Biol, 29, 8, (Apr 2009) 2092-104, 1098-5549

Bernstine, E. G., M. L. Hooper, S. Grandchamp and B. Ephrussi (1973). Alkaline Phosphatase Activity in Mouse Teratoma. Proc Natl Acad Sci U S A, 70, 12, (Dec 1973) 3899-3903, 0027-8424

Bongso, A., C. Y. Fong, S. C. Ng and S. Ratnam (1994). Isolation and culture of inner cell mass cells from human blastocysts. Hum Reprod, 9, 11, (Nov 1994) 2110-7, 0268-1161

Boyer, L. A., T. I. Lee, M. F. Cole, S. E. Johnstone, S. S. Levine, J. P. Zucker, M. G. Guenther, R. M. Kumar, H. L. Murray, R. G. Jenner, D. K. Gifford, D. A. Melton, R. Jaenisch and R. A. Young (2005). Core transcriptional regulatory circuitry in human embryonic stem cells. Cell, 122, 6, (Sep 2005) 947-56, 0092-8674

Bradley, A., M. Evans, M. H. Kaufman and E. Robertson (1984). Formation of germ-line chimaeras from embryo-derived teratocarcinoma cell lines. Nature, 309, 5965, (May 1984) 255-6, 0028-0836

Brederlau, A., A. S. Correia, S. V. Anisimov, M. Elmi, G. Paul, L. Roybon, A. Morizane, F. Bergquist, I. Riebe, U. Nannmark, M. Carta, E. Hanse, J. Takahashi, Y. Sasai, K. Funa, P. Brundin, P. S. Eriksson and J. Y. Li (2006). Transplantation of human embryonic stem cell-derived cells to a rat model of Parkinson's disease: effect of in vitro differentiation on graft survival and teratoma formation. Stem Cells, 24, 6, (Jun 2006) 1433-40, 1066-5099

Briggs, R. and T. J. King (1952). Transplantation of Living Nuclei From Blastula Cells into Enucleated Frogs' Eggs. Proc Natl Acad Sci U S A, 38, 5, (May 1952) 455-63, 00278424

Brons, I. G. M., L. E. Smithers, M. W. B. Trotter, P. Rugg-Gunn, B. Sun, S. M. Chuva de Sousa Lopes, S. K. Howlett, A. Clarkson, L. Ahrlund-Richter, R. A. Pedersen and L. Vallier (2007). Derivation of pluripotent epiblast stem cells from mammalian embryos. Nature, 448, 7150, (Jul 2007) 191-195, 1476-4687

Campbell, K. H., J. McWhir, W. A. Ritchie and I. Wilmut (1996). Sheep cloned by nuclear transfer from a cultured cell line. Nature, 380, 6569, (Mar 1996) 64-6, 0028-0836

Carter, M. G., C. A. Stagg, G. Falco, T. Yoshikawa, U. C. Bassey, K. Aiba, L. V. Sharova, N. Shaik and M. S. H. Ko (2008). An in situ hybridization-based screen for heterogeneously expressed genes in mouse ES cells. Gene Expr Patterns, 8, 3, (Feb 2008) 181-198, 1567-133X 
Cartwright, P., C. McLean, A. Sheppard, D. Rivett, K. Jones and S. Dalton (2005). LIF/STAT3 controls ES cell self-renewal and pluripotency by a Myc-dependent mechanism. Development, 132, 5, (Mar 2005) 885-96, 0950-1991

Chambers, I., D. Colby, M. Robertson, J. Nichols, S. Lee, S. Tweedie and A. Smith (2003). Functional expression cloning of Nanog, a pluripotency sustaining factor in embryonic stem cells. Cell, 113, 5, (May 2003) 643-55, 0092-8674

Chambers, I., J. Silva, D. Colby, J. Nichols, B. Nijmeijer, M. Robertson, J. Vrana, K. Jones, L. Grotewold and A. Smith (2007). Nanog safeguards pluripotency and mediates germline development. Nature, 450, 7173, (Dec 2007) 1230-1234, 1476-4687

Chambers, I. and A. Smith (2004). Self-renewal of teratocarcinoma and embryonic stem cells. Oncogene, 23, 43, (Sep 2004) 7150-60, 0950-9232

Chen, L. and J. S. Khillan (2008). Promotion of feeder-independent self-renewal of embryonic stem cells by retinol (vitamin A). Stem Cells, 26, 7, (Jul 2008) 1858-64, 1549-4918

Chen, L. and J. S. Khillan (2010). A novel signaling by vitamin A/retinol promotes self renewal of mouse embryonic stem cells by activating PI3K/Akt signaling pathway via insulin-like growth factor-1 receptor. Stem Cells, 28, 1, (Jan 2010) 57-63, 15494918

Cheng, J., A. Dutra, A. Takesono, L. Garrett-Beal and P. L. Schwartzberg (2004). Improved generation of C57BL/6J mouse embryonic stem cells in a defined serum-free media. Genesis, 39, 2, (Jun 2004) 100-4, 1526-954X

Chiang, M. K. and D. A. Melton (2003). Single-cell transcript analysis of pancreas development. Dev Cell, 4, 3, (Mar 2003) 383-93, 1534-5807

Chowdhury, F., S. Na, D. Li, Y. C. Poh, T. S. Tanaka, F. Wang and N. Wang (2010). Material properties of the cell dictate stress-induced spreading and differentiation in embryonic stem cells. Nat Mater, 9, 1, (Jan 2010) 82-8, 1476-1122

Chowdhury F., Y. Li, Y-C. Poh, T. Yokohama-Tamaki, N. Wang, and T.S. Tanaka (2010). Soft substrates promote self-renewal of embryonic stem cells by maintaining low tractions. PLoS ONE, 5, 12, (Dec 2010) e15655, 1932-6203

Crino, P., K. Khodakhah, K. Becker, S. Ginsberg, S. Hemby and J. Eberwine (1998). Presence and phosphorylation of transcription factors in developing dendrites. Proc Natl Acad Sci U S A, 95, 5, (Mar 1998) 2313-8, 0027-8424

Cross, D. A., D. R. Alessi, P. Cohen, M. Andjelkovich and B. A. Hemmings (1995). Inhibition of glycogen synthase kinase-3 by insulin mediated by protein kinase B. Nature, 378, 6559, (Dec 1995) 785-9, 0028-0836

Damjanov, I. and P. W. Andrews (2007). The terminology of teratocarcinomas and teratomas. Nat Biotechnol, 25, 11, (Nov 2007) 1212; discussion 1212, 1087-0156

Dani, C., I. Chambers, S. Johnstone, M. Robertson, B. Ebrahimi, M. Saito, T. Taga, M. Li, T. Burdon, J. Nichols and A. Smith (1998). Paracrine Induction of Stem Cell Renewal by LIF-Deficient Cells: A New ES Cell Regulatory Pathway. Dev Biol, 203, 1, (Nov 1998) 149-162, 0012-1606

Discher, D. E., D. J. Mooney and P. W. Zandstra (2009). Growth factors, matrices, and forces combine and control stem cells. Science, 324, 5935, (Jun 2009) 1673-7, 1095-9203

Engler, A. J., S. Sen, H. L. Sweeney and D. E. Discher (2006). Matrix elasticity directs stem cell lineage specification. Cell, 126, 4, (Aug 2006) 677-89, 0092-8674

Evans, M. J. and M. H. Kaufman (1981). Establishment in culture of pluripotential cells from mouse embryos. Nature, 292, 5819, (Jul 1981) 154-6, 0028-0836 
Falco, G., S.-L. Lee, I. Stanghellini, U. C. Bassey, T. Hamatani and M. S. H. Ko (2007). Zscan4: A novel gene expressed exclusively in late 2-cell embryos and embryonic stem cells. Dev Bio, 307, 2, (Jul 2007) 539-550, 0012-1606

Fujikura, J., E. Yamato, S. Yonemura, K. Hosoda, S. Masui, K. Nakao, J. Miyazaki Ji and H. Niwa (2002). Differentiation of embryonic stem cells is induced by GATA factors. Genes Dev, 16, 7, (Apr 2002) 784-9, 0890-9369

Furue, M., T. Okamoto, Y. Hayashi, H. Okochi, M. Fujimoto, Y. Myoishi, T. Abe, K. Ohnuma, G. H. Sato, M. Asashima and J. D. Sato (2005). Leukemia inhibitory factor as an anti-apoptotic mitogen for pluripotent mouse embryonic stem cells in a serum-free medium without feeder cells. In Vitro Cell Dev Biol Anim, 41, 1-2, (JanFeb 2005) 19-28, 1071-2690

Furue, M. K., J. Na, J. P. Jackson, T. Okamoto, M. Jones, D. Baker, R. Hata, H. D. Moore, J. D. Sato and P. W. Andrews (2008). Heparin promotes the growth of human embryonic stem cells in a defined serum-free medium. Proc Natl Acad Sci U S A, 105, 36, (Sep 2008) 13409-14, 1091-6490

Furusawa, T., K. Ohkoshi, C. Honda, S. Takahashi and T. Tokunaga (2004). Embryonic Stem Cells Expressing Both Platelet Endothelial Cell Adhesion Molecule-1 and StageSpecific Embryonic Antigen-1 Differentiate Predominantly into Epiblast Cells in a Chimeric Embryo. Biol Reprod, 70, 5, (May 2004) 1452-1457, 0006-3363

Furusawa, T., M. Ikeda, F. Inoue, K. Ohkoshi, T. Hamano and T. Tokunaga (2006). Gene Expression Profiling of Mouse Embryonic Stem Cell Subpopulations. Biol Reprod, 75, 4, (Oct 2006) 555-561, 0006-3363

Goldsborough, M. D., P. J. Price, J. Lobo-Alfonso, J. R. Morrison, M. E. Stevens, J. Meneses, R. Pedersen, B. Koller and A. Latour (1998). Serum-free culture of murine embryonic stem (ES) cells. Focus, 20, 1, (Jan 1998) 8-12,

Gurdon, J. B. and D. A. Melton (2008). Nuclear Reprogramming in Cells. Science, 322, 5909, (Dec 2008) 1811-1815, 1095-9203

Hanna, J., A. W. Cheng, K. Saha, J. Kim, C. J. Lengner, F. Soldner, J. P. Cassady, J. Muffat, B. W. Carey and R. Jaenisch (2010). Human embryonic stem cells with biological and epigenetic characteristics similar to those of mouse ESCs. Proc Natl Acad Sci U S A, 107, 20, (May 2010) 9222-7, 1091-6490

Hayashi, K., S. M. C. d. S. Lopes, F. Tang and M. A. Surani (2008). Dynamic Equilibrium and Heterogeneity of Mouse Pluripotent Stem Cells with Distinct Functional and Epigenetic States. Cell Stem Cell, 3, 4, (Oct 2008) 391-401, 1875-9777

Hayashi, Y., M. K. Furue, T. Okamoto, K. Ohnuma, Y. Myoishi, Y. Fukuhara, T. Abe, J. D. Sato, R.-I. Hata and M. Asashima (2007). Integrins Regulate Mouse Embryonic Stem Cell Self-Renewal. Stem Cells, 25, 12, (Dec 2007) 3005-3015, 1549-4918

Hayashi, Y., M. K. Furue, S. Tanaka, M. Hirose, N. Wakisaka, H. Danno, K. Ohnuma, S. Oeda, Y. Aihara, K. Shiota, A. Ogura, S. Ishiura and M. Asashima (2010). BMP4 induction of trophoblast from mouse embryonic stem cells in defined culture conditions on laminin. In Vitro Cell Dev Biol Anim, 46, 5, (May 2010) 416-30, 1543706X

He, T. C., A. B. Sparks, C. Rago, H. Hermeking, L. Zawel, L. T. da Costa, P. J. Morin, B. Vogelstein and K. W. Kinzler (1998). Identification of c-MYC as a target of the APC pathway. Science, 281, 5382, (Sep 1998) 1509-12, 0036-8075

Hewlett, G. (1991). Strategies for optimising serum-free media. Cytotechnology, 5, 1, (Jan 1991) 3-14, 0920-9069 
Hiratani, I., T. Ryba, M. Itoh, J. Rathjen, M. Kulik, B. Papp, E. Fussner, D. P. Bazett-Jones, K. Plath, S. Dalton, P. D. Rathjen and D. M. Gilbert (2010). Genome-wide dynamics of replication timing revealed by in vitro models of mouse embryogenesis. Genome Res, 20, 2, (Feb 2010) 155-69, 1549-5469

Holliday, M. A. (1999). Extracellular fluid and its proteins: dehydration, shock, and recovery. Pediatr Nephrol, 13, 9, (Nov 1999) 989-95, 0931-041X

Hosler, B. A., G. J. LaRosa, J. F. Grippo and L. J. Gudas (1989). Expression of REX-1, a gene containing zinc finger motifs, is rapidly reduced by retinoic acid in F9 teratocarcinoma cells. Mol Cell Bio., 9, 12, (Dec 1989) 5623-5629, 0270-7306

Ivanova, N. B., J. T. Dimos, C. Schaniel, J. A. Hackney, K. A. Moore and I. R. Lemischka (2002). A stem cell molecular signature. Science, 298, 5593, (Oct 2002) 601-4, 10959203

Jaenisch, R. and R. Young (2008). Stem Cells, the Molecular Circuitry of Pluripotency and Nuclear Reprogramming. Cell, 132, 4, (Feb 2008) 567-582, 1097-4172

James, D., A. J. Levine, D. Besser and A. Hemmati-Brivanlou (2005). TGFbeta/activin/nodal signaling is necessary for the maintenance of pluripotency in human embryonic stem cells. Development, 132, 6, (Mar 2005) 1273-82, 0950-1991

Jomura, S., M. Uy, K. Mitchell, R. Dallasen, C. J. Bode and Y. Xu (2007). Potential Treatment of Cerebral Global Ischemia with Oct-4+ Umbilical Cord Matrix Cells. Stem Cells, 25, 1, (Jan 2007) 98-106, 1066-5099

Kameda, T. and J. A. Thomson (2005). Human ERas gene has an upstream premature polyadenylation signal that results in a truncated, noncoding transcript. Stem Cells, 23, 10, (Nov-Dec 2005) 1535-40, 1066-5099

Kerr, D. A., J. Llado, M. J. Shamblott, N. J. Maragakis, D. N. Irani, T. O. Crawford, C. Krishnan, S. Dike, J. D. Gearhart and J. D. Rothstein (2003). Human Embryonic Germ Cell Derivatives Facilitate Motor Recovery of Rats with Diffuse Motor Neuron Injury. J. Neurosci., 23, 12, (Jun 2003) 5131-5140, 1529-2401

Kurimoto, K., Y. Yabuta, Y. Ohinata, Y. Ono, K. D. Uno, R. G. Yamada, H. R. Ueda and M. Saitou (2006). An improved single-cell cDNA amplification method for efficient high-density oligonucleotide microarray analysis. Nucleic Acids Res, 34, 5, (Mar 2006) e42, 1362-4962

Lako, M., S. Lindsay, J. Lincoln, P. M. Cairns, L. Armstrong and N. Hole (2001). Characterisation of Wnt gene expression during the differentiation of murine embryonic stem cells in vitro: role of Wnt3 in enhancing haematopoietic differentiation. Mech Dev, 103, 1-2, (May 2001) 49-59, 0925-4773

Lawrenz, B., H. Schiller, E. Wilbold, M. Ruediger, A. Muhs and S. Esser (2004) Highly sensitive biosafety model for stem-cell-derived grafts. Cytotherapy, 6, 3, (Jun 2004) 212-22, 1465-3249

Lensch, M. W. and T. A. Ince (2007). The terminology of teratocarcinomas and teratomas. Nat Biotechnol, 25, 11, (Nov 2007) 1211; author reply 1211-2, 1087-0156

Li, Y., J. McClintick, L. Zhong, H. J. Edenberg, M. C. Yoder and R. J. Chan (2005). Murine embryonic stem cell differentiation is promoted by SOCS-3 and inhibited by the zinc finger transcription factor Klf4. Blood, 105, 2, (Jan 2005) 635-7, 0006-4971

Lindsley, R. C., J. G. Gill, M. Kyba, T. L. Murphy and K. M. Murphy (2006). Canonical Wnt signaling is required for development of embryonic stem cell-derived mesoderm. Development, 133, 19, (Oct 2006) 3787-3796, 0950-1991

Loh, Y. H., Q. Wu, J. L. Chew, V. B. Vega, W. Zhang, X. Chen, G. Bourque, J. George, B. Leong, J. Liu, K. Y. Wong, K. W. Sung, C. W. Lee, X. D. Zhao, K. P. Chiu, L. 
Lipovich, V. A. Kuznetsov, P. Robson, L. W. Stanton, C. L. Wei, Y. Ruan, B. Lim and H. H. Ng (2006). The Oct4 and Nanog transcription network regulates pluripotency in mouse embryonic stem cells. Nat Genet, 38, 4, (Apr 2006) 431-40, 1061-4036

Loo, D. T., J. I. Fuquay, C. L. Rawson and D. W. Barnes (1987). Extended culture of mouse embryo cells without senescence: inhibition by serum. Science, 236, 4798, (Apr 1987) 200-2, 0036-8075

Ludwig, T. E., V. Bergendahl, M. E. Levenstein, J. Yu, M. D. Probasco and J. A. Thomson (2006a). Feeder-independent culture of human embryonic stem cells. Nat Methods, 3, 8, (Aug 2006) 637-46, 1548-7091

Ludwig, T. E., M. E. Levenstein, J. M. Jones, W. T. Berggren, E. R. Mitchen, J. L. Frane, L. J. Crandall, C. A. Daigh, K. R. Conard, M. S. Piekarczyk, R. A. Llanas and J. A. Thomson (2006b). Derivation of human embryonic stem cells in defined conditions. Nat Biotechnol, 24, 2, (Feb 2006) 185-7, 1087-0156

Martin, G. R. (1981). Isolation of a pluripotent cell line from early mouse embryos cultured in medium conditioned by teratocarcinoma stem cells. Proc Natl Acad Sci U S A, 78, 12, (Dec 1981) 7634-8, 0027-8424

Masui, S., Y. Nakatake, Y. Toyooka, D. Shimosato, R. Yagi, K. Takahashi, H. Okochi, A. Okuda, R. Matoba, A. A. Sharov, M. S. H. Ko and H. Niwa (2007). Pluripotency governed by Sox 2 via regulation of Oct $3 / 4$ expression in mouse embryonic stem cells. Nat Cell Biol, 9, 6, (Jun 2007) 625-635, 1465-7392

Masui, S., S. Ohtsuka, R. Yagi, K. Takahashi, M. Ko and H. Niwa (2008). Rex1/Zfp42 is dispensable for pluripotency in mouse ES cells. BMC Dev Bio, 8, 1, (Apr 2008) 45, 1471-213X

Matoba, R., H. Niwa, S. Masui, S. Ohtsuka, M. G. Carter, A. A. Sharov and M. S. Ko (2006). Dissecting oct3/4-regulated gene networks in embryonic stem cells by expression profiling. PLoS ONE, 1, (Dec 2006) e26, 1932-6203

Matsuda, T., T. Nakamura, K. Nakao, T. Arai, M. Katsuki, T. Heike and T. Yokota (1999). STAT3 activation is sufficient to maintain an undifferentiated state of mouse embryonic stem cells. Embo J, 18, 15, (Aug 1999) 4261-9, 0261-4189

Matsui, Y., D. Toksoz, S. Nishikawa, S. Nishikawa, D. Williams, K. Zsebo and B. L. Hogan (1991). Effect of Steel factor and leukaemia inhibitory factor on murine primordial germ cells in culture. Nature, 353, 6346, (Oct 1991) 750-2, 0028-0836

Matsui, Y., K. Zsebo and B. L. Hogan (1992). Derivation of pluripotential embryonic stem cells from murine primordial germ cells in culture. Cell, 70, 5, (Sep 1992) 841-7, 0092-8674

Melkoumian, Z., J. L. Weber, D. M. Weber, A. G. Fadeev, Y. Zhou, P. Dolley-Sonneville, J. Yang, L. Qiu, C. A. Priest, C. Shogbon, A. W. Martin, J. Nelson, P. West, J. P. Beltzer, S. Pal and R. Brandenberger (2010). Synthetic peptide-acrylate surfaces for long-term self-renewal and cardiomyocyte differentiation of human embryonic stem cells. Nat Biotechnol, 28, 6, (Jun 2010) 606-10, 1546-1696

Mitsui, K., Y. Tokuzawa, H. Itoh, K. Segawa, M. Murakami, K. Takahashi, M. Maruyama, M. Maeda and S. Yamanaka (2003). The homeoprotein Nanog is required for maintenance of pluripotency in mouse epiblast and ES cells. Cell, 113, 5, (May 2003) 631-42, 0092-8674

Nakagawa, M., N. Takizawa, M. Narita, T. Ichisaka and S. Yamanaka (2010). Promotion of direct reprogramming by transformation-deficient Myc. Proc Natl Acad Sci U S A, 107, 32, (Aug 2010) 14152-7, 1091-6490 
Nichols, J., B. Zevnik, K. Anastassiadis, H. Niwa, D. Klewe-Nebenius, I. Chambers, H. Scholer and A. Smith (1998). Formation of pluripotent stem cells in the mammalian embryo depends on the POU transcription factor Oct4. Cell, 95, 3, (Oct 1998) 379-91, 0092-8674

Niwa, H., T. Burdon, I. Chambers and A. Smith (1998). Self-renewal of pluripotent embryonic stem cells is mediated via activation of STAT3. Genes Dev., 12, 13, (July 1998) 2048-2060, 0890-9369

Niwa, H., J. Miyazaki and A. G. Smith (2000). Quantitative expression of Oct-3/4 defines differentiation, dedifferentiation or self-renewal of ES cells. Nat Genet, 24, 4, (Apr 2000) 372-6, 1061-4036

Niwa, H., Y. Toyooka, D. Shimosato, D. Strumpf, K. Takahashi, R. Yagi and J. Rossant (2005). Interaction between Oct $3 / 4$ and $\mathrm{Cdx} 2$ determines trophectoderm differentiation. Cell, 123, 5, (Dec 2005) 917-29, 0092-8674

Nordin, N., M. Li and J. O. Mason (2008). Expression profiles of Wnt genes during neural differentiation of mouse embryonic stem cells. Cloning Stem Cells, 10, 1, (Mar 2008) 37-48, 1536-2302

Okita, K., T. Ichisaka and S. Yamanaka (2007). Generation of germline-competent induced pluripotent stem cells. Nature, 448, 7151, (Jul 2007) 313-7, 1476-4687

Okoye, U. C., C. C. Malbon and H. Y. Wang (2008). Wnt and Frizzled RNA expression in human mesenchymal and embryonic (H7) stem cells. J Mol Signal, 3, (Sep 2008) 16, 1750-2187

Payer, B., S. M. Chuva de Sousa Lopes, S. C. Barton, C. Lee, M. Saitou and M. A. Surani (2006). Generation of stella-GFP transgenic mice: a novel tool to study germ cell development. Genesis, 44, 2, (Feb 2006) 75-83, 1526-954X

Polo, J. M., S. Liu, M. E. Figueroa, W. Kulalert, S. Eminli, K. Y. Tan, E. Apostolou, M. Stadtfeld, Y. Li, T. Shioda, S. Natesan, A. J. Wagers, A. Melnick, T. Evans and K. Hochedlinger (2010). Cell type of origin influences the molecular and functional properties of mouse induced pluripotent stem cells. Nat Biotechnol, 28, 8, (Aug 2010) 848-55, 1546-1696

Price, P. J., M. D. Goldsborough and M. L. Tilkins (1998). Embryonic stem cell serum replacement. International Patent Application. WO/ 1998/ 030679 (Jul 1998).

Rajala, K., H. Hakala, S. Panula, S. Aivio, H. Pihlajamaki, R. Suuronen, O. Hovatta and H. Skottman (2007). Testing of nine different xeno-free culture media for human embryonic stem cell cultures. Hum Reprod, 22, 5, (May 2007) 1231-8, 0268-1161

Ramalho-Santos, M., S. Yoon, Y. Matsuzaki, R. C. Mulligan and D. A. Melton (2002). "Stemness": transcriptional profiling of embryonic and adult stem cells. Science, 298, 5593, (Oct 2002) 597-600, 1095-9203

Ramos, C. A., T. A. Bowman, N. C. Boles, A. A. Merchant, Y. Zheng, I. Parra, S. A. Fuqua, C. A. Shaw and M. A. Goodell (2006). Evidence for Diversity in Transcriptional Profiles of Single Hematopoietic Stem Cells. PLoS Genet, 2, 9, (Sep 2006) 1553-7404, 1553-7404

Rathjen, J., J. A. Lake, M. D. Bettess, J. M. Washington, G. Chapman and P. D. Rathjen (1999). Formation of a primitive ectoderm like cell population, EPL cells, from ES cells in response to biologically derived factors. J Cell Sci, 112, 5, (Mar 1999) 601-12, 00219533

Rebuzzini, P., T. Neri, G. Mazzini, M. Zuccotti, C. A. Redi and S. Garagna (2008). Karyotype analysis of the euploid cell population of a mouse embryonic stem cell line revealed 
a high incidence of chromosome abnormalities that varied during culture. Cytogenet Genome Res, 121, 1, (Jun 2008) 18-24, 1424-859X

Rideout, W. M., 3rd, K. Hochedlinger, M. Kyba, G. Q. Daley and R. Jaenisch (2002). Correction of a genetic defect by nuclear transplantation and combined cell and gene therapy. Cell, 109, 1, (Apr 2002) 17-27, 0092-8674

Robertson, E. J. (1987). Embryo-derived stem cell lines, In: Teratocarcinomas and embryonic stem cells: A practcal approach, E. J. Robertson, (Ed.), 71-112, IRL Press Ltd., 1-85221004-4, Oxford

Rodin, S., A. Domogatskaya, S. Strom, E. M. Hansson, K. R. Chien, J. Inzunza, O. Hovatta and K. Tryggvason (2010). Long-term self-renewal of human pluripotent stem cells on human recombinant laminin-511. Nat Biotechnol, 28, 6, (Jun 2010) 611-5, 15461696

Sato, G. H. (1975). The role of serum in cell culture, In: Biochemical Actions of Hormones, G. Litwack, (Ed.) 3: 391-396, Academic Press, B001D89UWC, New York

Sato, G. H., J. D. Sato, T. Okamoto, W. L. McKeehan and D. W. Barnes (2010). Tissue culture: the unlimited potential. In Vitro Cell Dev Biol Anim, 46, 7, (Jul 2010) 590-4, 1543-706X

Sato, N., L. Meijer, L. Skaltsounis, P. Greengard and A. H. Brivanlou (2004). Maintenance of pluripotency in human and mouse embryonic stem cells through activation of Wnt signaling by a pharmacological GSK-3-specific inhibitor. Nat Med, 10, 1, (Jan 2004) 55-63, 1078-8956

Schenke-Layland, K., E. Angelis, K. E. Rhodes, S. Heydarkhan-Hagvall, H. K. Mikkola and W. R. MacLellan (2007). Collagen IV Induces Trophoectoderm Differentiation of Mouse Embryonic Stem Cells. Stem Cells, 25, 6, (Jun 2007) 1529-1538, 1066-5099

Shamblott, M. J., J. Axelman, S. Wang, E. M. Bugg, J. W. Littlefield, P. J. Donovan, P. D. Blumenthal, G. R. Huggins and J. D. Gearhart (1998). Derivation of pluripotent stem cells from cultured human primordial germ cells. Proc Natl Acad Sci U S A, 95, 23, (Nov 1998) 13726-31, 0027-8424

Sharova, L. V., A. A. Sharov, Y. Piao, N. Shaik, T. Sullivan, C. L. Stewart, B. L. M. Hogan and M. S. H. Ko (2007). Global gene expression profiling reveals similarities and differences among mouse pluripotent stem cells of different origins and strains. Dev Biol, 307, 2, (Jul 2007) 446-459, 0012-1606

Shen, M. M. and P. Leder (1992). Leukemia Inhibitory Factor is Expressed by the Preimplantation Uterus and Selectively Blocks Primitive Ectoderm Formation in vitro. Proc Natl Acad Sci U S A, 89, 17, (Sep 1992) 8240-8244, 0027-8424

Singh, A. M., T. Hamazaki, K. E. Hankowski and N. Terada (2007). A Heterogeneous Expression Pattern for Nanog in Embryonic Stem Cells. Stem Cells, 25, 10, (Oct 2007) 2534-2542, 1549-4918

Smith, A. G., J. K. Heath, D. D. Donaldson, G. G. Wong, J. Moreau, M. Stahl and D. Rogers (1988). Inhibition of pluripotential embryonic stem cell differentiation by purified polypeptides. Nature, 336, 6200, (Dec 1988) 688-90, 0028-0836

Smith, T. A. and M. L. Hooper (1983). Medium conditioned by feeder cells inhibits the differentiation of embryonal carcinoma cultures. Exp Cell Res, 145, 2, (May 1983) 458-462, 0014-4827

Solter, D. (2006). From teratocarcinomas to embryonic stem cells and beyond: a history of embryonic stem cell research. Nat Rev Genet, 7, 4, (Apr 2006) 319-27, 1471-0056

Stevens, L. C. (1970). The development of transplantable teratocarcinomas from intratesticular grafts of pre- and postimplantation mouse embryos. Dev Biol, 21, 3, (Mar 1970) 364-382, 0012-1606 
Stevens, L. C. (1973). A new inbred subline of mice (129-terSv) with a high incidence of spontaneous congenital testicular teratomas. J Natl Cancer Inst, 50, 1, (Jan 1973) 235$42,0027-8874$

Stevens, L. C. and C. C. Little (1954). Spontaneous Testicular Teratomas in an Inbred Strain of Mice. Proc Natl Acad Sci U S A, 40, 11, (Nov 1954) 1080-7, 0027-8424

Suemori, H., T. Tada, R. Torii, Y. Hosoi, K. Kobayashi, H. Imahie, Y. Kondo, A. Iritani and N. Nakatsuji (2001). Establishment of embryonic stem cell lines from cynomolgus monkey blastocysts produced by IVF or ICSI. Dev Dyn, 222, 2, (Oct 2001) 273-9, 1058-8388

Suzuki, A., A. Raya, Y. Kawakami, M. Morita, T. Matsui, K. Nakashima, F. H. Gage, C. Rodriguez-Esteban and J. C. Belmonte (2006a). Maintenance of embryonic stem cell pluripotency by Nanog-mediated reversal of mesoderm specification. Nat Clin Pract Cardiovasc Med, 3 Suppl 1, (Mar 2006) S114-22, 1743-4297

Suzuki, A., A. Raya, Y. Kawakami, M. Morita, T. Matsui, K. Nakashima, F. H. Gage, C. Rodriguez-Esteban and J. C. Izpisua Belmonte (2006b). Nanog binds to Smad1 and blocks bone morphogenetic protein-induced differentiation of embryonic stem cells. Proc Natl Acad Sci U S A, 103, 27, (Jul 2006) 10294-9, 0027-8424

Takahashi, K., K. Mitsui and S. Yamanaka (2003). Role of ERas in promoting tumour-like properties in mouse embryonic stem cells. Nature, 423, 6939, (May 2003) 541-5, 0028-0836

Takahashi, K. and S. Yamanaka (2006). Induction of pluripotent stem cells from mouse embryonic and adult fibroblast cultures by defined factors. Cell, 126, 4, (Aug 2006) 663-676, 0092-8674

Takahashi, K., K. Tanabe, M. Ohnuki, M. Narita, T. Ichisaka, K. Tomoda and S. Yamanaka (2007). Induction of Pluripotent Stem Cells from Adult Human Fibroblasts by Defined Factors. Cell, 131, 5, (Nov 2007) 861-72, 0092-8674

Tanaka, T. S. (2009). Transcriptional heterogeneity in mouse embryonic stem cells. Reprod Fertil Dev, 21, 1, (Jan 2009) 67-75, 1031-3613

Tanaka, T. S. (2010). Stem Cell Research, In: Encyclopedia of Biotechnology in Agriculture and Food, D. R. Heldman, D. G. Hoover and M. B. Wheeler, (Ed.) 1: 597-603, Informa Ltd., 0849350271, London

Tanaka, T. S., T. Kunath, W. L. Kimber, S. A. Jaradat, C. A. Stagg, M. Usuda, T. Yokota, H. Niwa, J. Rossant and M. S. Ko (2002). Gene expression profiling of embryo-derived stem cells reveals candidate genes associated with pluripotency and lineage specificity. Genome Res, 12, 12, (Dec 2002) 1921-8, 1088-9051

Tanaka, T. S., I. Lopez de Silanes, L. V. Sharova, H. Akutsu, T. Yoshikawa, H. Amano, S. Yamanaka, M. Gorospe and M. S. Ko (2006). Esg1, expressed exclusively in preimplantation embryos, germline, and embryonic stem cells, is a putative RNAbinding protein with broad RNA targets. Dev Growth Differ, 48, 6, (Aug 2006), 38190, 0012-1592

Tanaka, T. S., R. E. Davey, Q. Lan, P. W. Zandstra and W. L. Stanford (2008). Development of a gene trap vector with a highly-sensitive fluorescent protein reporter system aiming for the real-time single cell expression profiling. Genesis, 46, 7, (Jul 2008) 347-356, 1526-968X

Tanaka, Y., T. Ikeda, Y. Kishi, S. Masuda, H. Shibata, K. Takeuchi, M. Komura, T. Iwanaka, S. Muramatsu, Y. Kondo, K. Takahashi, S. Yamanaka and Y. Hanazono (2009). ERas is expressed in primate embryonic stem cells but not related to tumorigenesis. Cell Transplant, 18, 4, (Apr 2009) 381-9, 0963-6897 
Tang, F., C. Barbacioru, S. Bao, C. Lee, E. Nordman, X. Wang, K. Lao and M. A. Surani (2010). Tracing the derivation of embryonic stem cells from the inner cell mass by single-cell RNA-Seq analysis. Cell Stem Cell, 6, 5, (May 2010) 468-78, 1875-9777

Tesar, P. J., J. G. Chenoweth, F. A. Brook, T. J. Davies, E. P. Evans, D. L. Mack, R. L. Gardner and R. D. G. McKay (2007). New cell lines from mouse epiblast share defining features with human embryonic stem cells. Nature, 448, 7150, (Jul 2007) 196-199, $1476-4687$

Thomson, J. A., J. Itskovitz-Eldor, S. S. Shapiro, M. A. Waknitz, J. J. Swiergiel, V. S. Marshall and J. M. Jones (1998). Embryonic stem cell lines derived from human blastocysts. Science, 282, 5391, (Nov 1998) 1145-7, 0036-8075

Toyooka, Y., D. Shimosato, K. Murakami, K. Takahashi and H. Niwa (2008). Identification and characterization of subpopulations in undifferentiated ES cell culture. Development, 135, 5, (Mar 2008) 909-918, 0950-1991

Umehara, H., T. Kimura, S. Ohtsuka, T. Nakamura, K. Kitajima, M. Ikawa, M. Okabe, H. Niwa and T. Nakano (2007). Efficient derivation of embryonic stem cells by inhibition of glycogen synthase kinase-3. Stem Cells, 25, 11, (Nov 2007) 2705-11, $1549-4918$

Vallier, L., M. Alexander and R. A. Pedersen (2005). Activin/Nodal and FGF pathways cooperate to maintain pluripotency of human embryonic stem cells. J Cell Sci, 118, 19, (Oct 2005) 4495-509, 0021-9533

Villa-Diaz, L. G., H. Nandivada, J. Ding, N. C. Nogueira-de-Souza, P. H. Krebsbach, K. S. O'Shea, J. Lahann and G. D. Smith (2010). Synthetic polymer coatings for long-term growth of human embryonic stem cells. Nat Biotechnol, 28, 6, (Jun 2010) 581-3, 15461696

Voog, J. and D. L. Jones (2010). Stem cells and the niche: a dynamic duo. Cell Stem Cell, 6, 2, (Feb 2010) 103-15, 1875-9777

Wakayama, T., A. C. Perry, M. Zuccotti, K. R. Johnson and R. Yanagimachi (1998). Full-term development of mice from enucleated oocytes injected with cumulus cell nuclei. Nature, 394, 6691, (Jul 1998) 369-74, 0028-0836

Walker, E., E. Ohishi, R. E. Davey, W. Zhang, P. A. Cassar, T. S. Tanaka, S. D. Der, Q. Morris, T. R. Hughes, P. W. Zandstra and W. L. Stanford (2007). Prediction and Testing of Novel Transcriptional Networks Regulating Embryonic Stem Cell Self-Renewal and Commitment. Cell Stem Cell, 1, 1, (Jun 2007) 71-86, 1875-9777

Wang, G., H. Zhang, Y. Zhao, J. Li, J. Cai, P. Wang, S. Meng, J. Feng, C. Miao, M. Ding, D. Li and H. Deng (2005). Noggin and bFGF cooperate to maintain the pluripotency of human embryonic stem cells in the absence of feeder layers. Biochem Biophys Res Commun, 330, 3, (May 2005) 934-42, 0006-291X

Wang, J., P. Alexander, L. Wu, R. Hammer, O. Cleaver and S. L. McKnight (2009). Dependence of mouse embryonic stem cells on threonine catabolism. Science, 325, 5939, (Jul 2009) 435-9, 1095-9203

Wang, R., J. Liang, H. M. Yu, H. Liang, Y. J. Shi and H. T. Yang (2008). Retinoic acid maintains self-renewal of murine embryonic stem cells via a feedback mechanism. Differentiation, 76, 9, (Nov 2008) 931-45, 1432-0436

Wang, Y. and N. Nakayama (2009). WNT and BMP signaling are both required for hematopoietic cell development from human ES cells. Stem Cell Res, 3, 2-3, (SepNov 2009) 113-25, 1876-7753 
Watanabe, S., H. Umehara, K. Murayama, M. Okabe, T. Kimura and T. Nakano (2006). Activation of Akt signaling is sufficient to maintain pluripotency in mouse and primate embryonic stem cells. Oncogene, 25, 19, (May 2006) 2697-707, 0950-9232

Western, P., J. Maldonado-Saldivia, J. van den Bergen, P. Hajkova, M. Saitou, S. Barton and M. A. Surani (2005). Analysis of Esg1 expression in pluripotent cells and the germline reveals similarities with Oct4 and Sox 2 and differences between human pluripotent cell lines. Stem Cells, 23, 10, (Nov-Dec 2005), 1436-42, 1066-5099

Wilder, P. J., D. Kelly, K. Brigman, C. L. Peterson, T. Nowling, Q.-S. Gao, R. D. McComb, M. R. Capecchi and A. Rizzino (1997). Inactivation of the FGF-4 Gene in Embryonic Stem Cells Alters the Growth and/or the Survival of Their Early Differentiated Progeny. Dev Biol, 192, 2, (Dec 1997) 614-629, 0012-1606

Williams, R. L., D. J. Hilton, S. Pease, T. A. Willson, C. L. Stewart, D. P. Gearing, E. F. Wagner, D. Metcalf, N. A. Nicola and N. M. Gough (1988). Myeloid leukaemia inhibitory factor maintains the developmental potential of embryonic stem cells. Nature, 336, 6200, (Dec 1988) 684-7, 0028-0836

Wu, D. and W. Pan (2010). GSK3: a multifaceted kinase in Wnt signaling. Trends Biochem Sci, 35, 3, (Mar 2010) 161-168, 0968-0004

Xu, C., E. Rosler, J. Jiang, J. S. Lebkowski, J. D. Gold, C. O'Sullivan, K. Delavan-Boorsma, M. Mok, A. Bronstein and M. K. Carpenter (2005a). Basic fibroblast growth factor supports undifferentiated human embryonic stem cell growth without conditioned medium. Stem Cells, 23, 3, (Mar 2005) 315-23, 1066-5099

Xu, R. H., X. Chen, D. S. Li, R. Li, G. C. Addicks, C. Glennon, T. P. Zwaka and J. A. Thomson (2002). BMP4 initiates human embryonic stem cell differentiation to trophoblast. Nat Biotechnol, 20, 12, (Dec 2002) 1261-4, 1087-0156

Xu, R. H., R. M. Peck, D. S. Li, X. Feng, T. Ludwig and J. A. Thomson (2005b). Basic FGF and suppression of BMP signaling sustain undifferentiated proliferation of human ES cells. Nat Methods, 2, 3, (Mar 2005) 185-90, 1548-7091

Yamanaka, S. (2009). A fresh look at iPS cells. Cell, 137, 1, (Apr 2009) 13-7, 1097-4172

Yanes, O., J. Clark, D. M. Wong, G. J. Patti, A. Sanchez-Ruiz, H. P. Benton, S. A. Trauger, C. Desponts, S. Ding and G. Siuzdak (2010). Metabolic oxidation regulates embryonic stem cell differentiation. Nat Chem Biol, 6, 6, (Jun 2010) 411-7, 1552-4469

Ying, Q. L., J. Nichols, I. Chambers and A. Smith (2003). BMP induction of Id proteins suppresses differentiation and sustains embryonic stem cell self-renewal in collaboration with STAT3. Cell, 115, 3, (Oct 2003) 281-92, 0092-8674

Ying, Q.-L., J. Wray, J. Nichols, L. Batlle-Morera, B. Doble, J. Woodgett, P. Cohen and A. Smith (2008). The ground state of embryonic stem cell self-renewal. Nature, 453, 7194, (May 2008) 519-523, 1476-4687

Yu, J., M. A. Vodyanik, K. Smuga-Otto, J. Antosiewicz-Bourget, J. L. Frane, S. Tian, J. Nie, G. A. Jonsdottir, V. Ruotti, R. Stewart, I. I. Slukvin and J. A. Thomson (2007). Induced pluripotent stem cell lines derived from human somatic cells. Science, 318, 5858, (Dec 2007) 1917-20, 1095-9203

$\mathrm{Yu}, \mathrm{J}$. and J. A. Thomson (2008). Pluripotent stem cell lines. Genes Dev., 22, 15, (Aug 2008) 1987-1997, 0890-9369

Zalzman, M., G. Falco, L. V. Sharova, A. Nishiyama, M. Thomas, S. L. Lee, C. A. Stagg, H. G. Hoang, H. T. Yang, F. E. Indig, R. P. Wersto and M. S. Ko (2010). Zscan4 regulates telomere elongation and genomic stability in ES cells. Nature, 464, 7290, (Apr 2010) 858-63, 1476-4687 


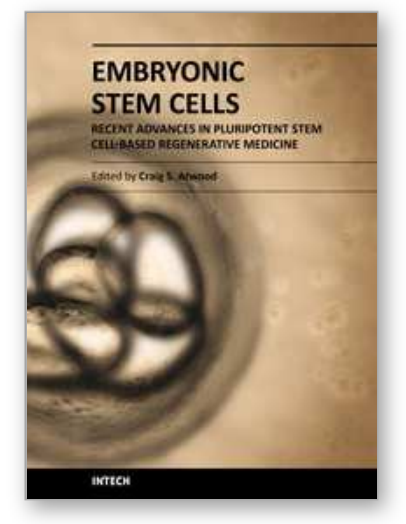

\section{Embryonic Stem Cells - Recent Advances in Pluripotent Stem Cell- Based Regenerative Medicine}

Edited by Prof. Craig Atwood

ISBN 978-953-307-198-5

Hard cover, 410 pages

Publisher InTech

Published online 26, April, 2011

Published in print edition April, 2011

Pluripotent stem cells have the potential to revolutionise medicine, providing treatment options for a wide range of diseases and conditions that currently lack therapies or cures. This book describes recent advances in the generation of tissue specific cell types for regenerative applications, as well as the obstacles that need to be overcome in order to recognize the potential of these cells.

\section{How to reference}

In order to correctly reference this scholarly work, feel free to copy and paste the following:

Yanzhen Li and Tetsuya S. Tanaka (2011). Self-Renewal, Pluripotency and Tumorigenesis in Pluripotent Stem Cells Revisited, Embryonic Stem Cells - Recent Advances in Pluripotent Stem Cell-Based Regenerative Medicine, Prof. Craig Atwood (Ed.), ISBN: 978-953-307-198-5, InTech, Available from:

http://www.intechopen.com/books/embryonic-stem-cells-recent-advances-in-pluripotent-stem-cell-basedregenerative-medicine/self-renewal-pluripotency-and-tumorigenesis-in-pluripotent-stem-cells-revisited

\section{INTECH}

open science | open minds

\author{
InTech Europe \\ University Campus STeP Ri \\ Slavka Krautzeka 83/A \\ 51000 Rijeka, Croatia \\ Phone: +385 (51) 770447 \\ Fax: +385 (51) 686166 \\ www.intechopen.com
}

\author{
InTech China \\ Unit 405, Office Block, Hotel Equatorial Shanghai \\ No.65, Yan An Road (West), Shanghai, 200040, China \\ 中国上海市延安西路65号上海国际贵都大饭店办公楼 405 单元 \\ Phone: +86-21-62489820 \\ Fax: $+86-21-62489821$
}


(C) 2011 The Author(s). Licensee IntechOpen. This chapter is distributed under the terms of the Creative Commons Attribution-NonCommercialShareAlike-3.0 License, which permits use, distribution and reproduction for non-commercial purposes, provided the original is properly cited and derivative works building on this content are distributed under the same license. 